\title{
Study Site Lead Indicator
}

National Cancer Institute

\section{Source}

National Cancer Institute. Study Site Lead Indicator. NCI Thesaurus. Code C94142.

Specifies whether this is the principal administrative organization responsible for the study. 